\title{
Welcome to the New Originalism: A Comment on Jack Balkin's Living Originalism
}

Randy E. Barnett

Georgetown University Law Center, rb325@law.georgetown.edu

Georgetown Public Law and Legal Theory Research Paper No. 13-026

This paper can be downloaded free of charge from:

https://scholarship.law.georgetown.edu/facpub/1194

http://ssrn.com/abstract=2243115

Jerusalem Rev. of Legal Stud. 1-7 (March 27, 2013), http://jrls.oxfordjournals.org/content/early/ 2013/03/27/jrls.jlt001.full.pdf+html

This open-access article is brought to you by the Georgetown Law Library. Posted with permission of the author. Follow this and additional works at: https://scholarship.law.georgetown.edu/facpub

Part of the Constitutional Law Commons 


\title{
Welcome to the New Originalism: A Comment on Jack Balkin's Living Originalism
}

\author{
Randy E Barnett*
}

I am delighted to contribute to this symposium on what is sure to become a staple of constitutional scholarship, Jack Balkin's recent book Living Originalism. ${ }^{1}$ I stand by my comments on the book jacket: "Living Originalism is the best and most important work in constitutional theory since Dworkin's Law's Empire. ${ }^{2}$ Despite my deep disagreement with several of its key claims, it is without doubt a work of remarkable sophistication, maturity and grace. Jack Balkin is already in the upper echelon of today's constitutional scholars, but this book puts him at the top of the top." The most newsworthy thing about the book's publication is simply that Jack Balkin has adopted originalism as his own.

This is not to deny that I have deep disagreements with portions of the book. Indeed, I have written separately and more in depth about our differing views on the commerce clause ${ }^{3}$ and underlying principles. ${ }^{4}$ In this essay, I will focus on Balkin's nuanced approach to interpretation that marks his great contribution to constitutional theory. To appreciate his position, I will discuss how and why a nonoriginalist can become an originalist. I, for one, was not an originalist until the end of the last century. By discussing how I eventually became one, I hope to shed some light on what exactly is so remarkable about Jack Balkin's move.

\section{The three main problems with originalism: intentions, indeterminacy, and legitimacy}

Having been a student of Ronald Dworkin and finding his approach in Law's Empire very appealing, as a young law professor I would have described myself

^ Carmack Waterhouse Professor of Legal Theory, Georgetown University Law Center. Email: rbarnett@gmail. com. This article is based on remarks given at the "Symposium on Jack M. Balkin, Living Originalism," held at Hebrew University on 18 May 2012. My thanks to Alisa Melekhina for her invaluable assistance on this essay.

${ }^{1}$ Jack M. Balkin, Living Originalism (2011).

2 Ronald Dworkin, Law's Empire (1986).

${ }^{3}$ It is difficult to discuss our disagreement on the commerce clause here because if you are an originalist, these are disagreements that are handled by appealing to evidence. To be convincing, a more comprehensive presentation of evidence is required than is possible in this brief comment. See Randy E. Barnett, Fack Balkin's Interaction Theory of "Commerce", 2012 U. Ill. L. REv. 623 (2011).

${ }^{4}$ See Randy E. Barnett, Underlying Principles, 24 Const. Comment 405 (2007).

(C) The Author 2013. Published by Oxford University Press. All rights reserved. For Permissions, please email: journals.permissions@oup.com 
as a "Dworkinian." My three principal dissatisfactions with originalism, which still persist today, were with intentions, indeterminacy, and legitimacy.

When originalism began to be identified as a discernible theory of interpretation, it was formulated in terms of trying to respect the intentions of the framers of the Constitution. This is now known as original intent originalism. The problem with using intentions was laid bare by Paul Brest in his influential 1980 article criticizing originalism. ${ }^{5} \mathrm{He}$ recognized that since intentions exist in people's minds, it is difficult to discern what those intentions are. But it is especially problematic to hypothesize a "collective intent" of multiple minds. This deep incoherence was certainly troubling to me and I accepted it as a valid criticism.

Instead of finding evidence as to what the framers intended on a particular matter, an old originalist would have to "channel" them. Take, for example, whether the thermal imaging of a house, to determine whether the occupants are growing marijuana in the basement, is a search for purposes of the Fourth Amendment. The framers would obviously have been unaware of this modern technology. So originalists would typically have to channel the framers by asking the counterfactual question, "Oh framers, what would you think about the thermal imaging of a house?" Because this is not a factual question, the framers' intentions would be discerned by employing a counterfactual thought experiment, rather than engaging in a historical investigation based on evidence.

The second related criticism of indeterminacy potentially applies as well to other versions of originalism. It presents the challenge that Constitution's meaning is not specific enough, and does not convey enough information to bind judges and decision-makers. I will return to this momentarily.

Additionally, the third well-known problem of originalism, the issue of legitimacy, seemed to me telling. Why we should care and furthermore be authoritatively bound by the intentions of those long-dead ancestors or, in my case, someone else's long-dead ancestors? This problem led me to pejoratively characterize this version of originalism as the "framers as wardens" approach. ${ }^{6}$ To old originalists, the framers were somehow authoritative wardens, similar to how prisoners must obey their prison wardens.

\section{My path from nonoriginalism to originalism}

Notwithstanding these pressing problems, I came to be an originalist in an unusual way. I did not get to it because of a theoretical discovery or because I read some contemporary scholarship on the subject. Instead, while teaching a seminar on constitutional theory, I happened to come across the writings of a

\footnotetext{
${ }^{5}$ Paul Brest, The Misconceived Quest for the Original Understanding, 60 B.U. L. REv. 204 (1980). Indeed, in this article, Brest first coined the term "originalism."

${ }^{6}$ See Randy E. Barnett, The Relevance of the Framers' Intent, 19 Harv. J.L. \& Pub. Pol'y 403 (1995) ("I shall discuss two reasons to consult the Framers. The first views the Framers as wardens; the second as designers or architects.").
} 
19th century abolitionist legal theorist named Lysander Spooner, whose approach to interpretation had been remarkably influential among abolitionist constitutional theorists prior to the Civil War.

In 1845 Spooner published The Unconstitutionality of Slavery ${ }^{7}$ long before the Thirteenth Amendment abolished slavery. He argued that the Constitution did not actually protect slavery, but was in fact anti-slavery. This struck me as quite counterintuitive to say the least. He reached this conclusion by using a version of originalism that was unfamiliar to me.

Garrisonian critics of the Constitution who had argued that the Constitution was pro-slavery based their argument on the pro-slavery intentions of the framers of the Constitution. ${ }^{8}$ So too did Chief Justice Taney use intentionalism in Dred Scott. ${ }^{9}$ In contrast, Spooner employed what has now come to be called original public meaning originalism. According to Spooner, the Constitution,

independently of the actual intentions of the people, expresses some certain fixed, definite, and legal intentions; else the people themselves would express no intentions by agreeing to it $^{10}[\ldots]$ The intentions of the framers of the constitution $[\ldots]$ have nothing to do with fixing the legal meaning of the constitution. That convention were not delegated to adopt or establish a constitution; but only to consult, devise and recommend. The instrument, when it came from their hands, was a mere proposal, having no legal force or authority. It finally derived all its validity and obligation, as a frame of government, from its adoption by the people at large. ${ }^{11}$

My attraction to Spooner's approach did not, and does not, depend on whether his conclusion about the Constitution's position on slavery was correct. What attracted me was the promise of this version of originalism to respond to deficiencies of the old originalism. ${ }^{12}$ And, unbeknownst to me, other originalists, such as Justice Antonin Scalia and political theories Keith Whittington, were already moving in the direction toward this new originalism.

\section{How the new originalism addresses the three problems with the old originalism}

The new originalism effectively responds to the difficulties of the old originalism. First, rather than resting on the framers' intentions, new originalism

\footnotetext{
7 See Lysander Spooner, The Unconstitutionality of Slavery (rev. ed.1860), reprinted in 4 The Collected Works Of Lysander Spooner (Charles Shively ed., 1971). For a discussion of the constitutional abolitionist movement of which Spooner was a part, see Randy E. Barnett, Whence Comes Section One? The Abolitionist Origin of the Fourteenth Amendment, 3 J. of Legal Analysis 165 (2011).

${ }^{8} \mathrm{See}$ eg Wendell Phillips, The Constitution, A Pro-Slavery Compact (1845).

${ }^{9}$ See Dred Scott v Sandford, 60 U.S. 393 (1857).

${ }^{10}$ Spooner, supra note 7 at 222 .

$11 \mathrm{Id}$. at 114 .

${ }^{12}$ It is possible also to distinguish Spooner's approach from the best modern version of original public meaning originalism, for example, with regard to his stress on the "legal" meaning of the text. But that distinction, if warranted, was not apparent to me when I first read Spooner and was influenced by him to reconsider originalism. See Randy E. Barnett, Was Slavery Unconstitutional Before the Thirteenth Amendment?, Lysander Spooner's Theory of Interpretation, 28 PAC. L.J. 977 (1997).
} 
is premised on determining the original public meaning of the text of the Constitution. Putting this into more familiar contract law terms, the theory relies on the Constitution's objective public meaning rather than the subjective intentions of the framers. ${ }^{13}$ The Constitution's text is objective in that it is a social construct that is independent of any particular person's opinion or preferences about the meaning of language. To communicate with others requires us to learn a "common" language that is necessarily independent of our own will and intentions. We must understand and make ourselves understood by invoking this common language.

While language is thus a human artifact and does not exist independently of human thought, it does exist independently of any one of our intentions about it. Even though there is an expressed, implied, and contextual meaning, they are all objective in the sense that they are independent of the internal mental states of the people who invoke the social convention called language. Language is not simply a social and rational enterprise-it is discernable. If we can discern it today, we can discern it from yesterday. This ability renders the new originalism far more practical than the old originalism with its search for the collective intentions of the framers.

One would expect that, if the Constitution's framers were being careful, their subjective intentions would track the public meaning of the words they chose. Hence, it is no accident that this objective meaning closely correlates with the subjective intentions we are able to discern. By invoking this independently existing meaning, the framers transformed whatever internal intentions they harbored into an externally perceivable intention, or from their subjective intentions to an objective semantic meaning.

Of course, it is possible that the resulting objective meaning might conflict with their subjective intentions. However, such divergence is unlikely to be commonplace if the framers were careful. Spooner claimed that at least some of the people who wrote the text did not want to write what they truly thought. Because they knew that slavery is wrong, they deliberately employed euphemisms. A euphemism is a word or phrase with a good meaning that is used to refer to something bad. What do we do when the authors of a constitution write this way? Spooner contended that we are only bound by the "good" or innocent meaning of the text, not by the intention. ${ }^{14}$

In addition to relying on original public meaning, the new originalism addresses the problem of indeterminacy by distinguishing between the activity

\footnotetext{
${ }^{13}$ I want to make it clear that as someone who takes contracts and contractual consent very seriously, I do not think the Constitution qualifies as a contract. However, it is a writing and shares some attributes with written contracts. Among these is that there is a semantic, objective public meaning of the text that is distinct from the subjective intentions of the people who drafted the document. On this distinction, see Randy E. BarnETt, Restoring the Lost Constitution: The Presumption of Liberty 14-25, 40-45 (2004).

${ }^{14}$ I discuss the problem of intentional ambiguity created by euphemistic language in the context of slavery and the Constitution, in Randy E. Barnett, The Misconceived Assumption About Constitutional Assumptions, 103 Nw. U. L. Rev. 615, 633, 641, 648-50 (2009).
} 
of identifying the communicative meaning of the text and the activity of applying that meaning to particular factual situations. When the text does not contain enough information to resolve a particular case or controversy, something else must be done to supplement it. When the text of the Constitution does not contain all the information required to render a decision, the new originalism acknowledges the need for decision-makers to adopt other decision-making rules, principles, or standards to put the information it does supply into effect.

Princeton professor Keith Whittington was the first of the new originalists to differentiate between these two key activities that had previously been run together. He called the first activity of identifying the information conveyed by the text "constitutional interpretation," and the second activity of applying that meaning to particular cases "constitutional construction." 15 The distinction between interpretation and construction was a traditional doctrine in American legal practice. Though it was largely lost in the 20th century, it features prominently in Living Originalism.

According to new originalists, originalism is a theory of constitutional interpretation as opposed to construction. Whereas originalism used to claim to be a closed enterprise that obtains results, the new originalism takes originalist interpretation as far as it can go, and then recognizes that an element of nonoriginalist construction is required to go farther. When the need to supplement originalist interpretation with nonoriginalist construction is acknowledged, originalism becomes much more open-ended enterprise than it was previously claimed to be. This has created resistance from some originalists. ${ }^{16}$

The most significant contribution of the new originalism may be that it addresses the crucial problem of legitimacy. Rather than dictating that the American people must be bound by the intentions of their ancestors, the new originalism views the Constitution as the law that governs those who govern the American people. Because the people are a mass who do not have a single mind or voice, a written constitution is the only authoritative "voice" of the people. Where it speaks, the servants of the people must obey. Just as you or I cannot change the traffic laws that are imposed upon us without going through the legislative process, the strategy of using a written law to oversee those who govern us simply will not work if those who are to be governed by this law can change its meaning without going through the amendment process.

For this reason, the meaning of the written Constitution should remain the same until it is properly changed, which is simply a short-hand way of describing originalism. And the proper way of changing the American Constitution is by constitutional amendment.

\footnotetext{
15 See Keith E. Whittington, Constitutional Interpretation: Textual Meaning, Original Intent, \& Judicial ReVIEW (1999).

${ }^{16}$ See, eg, John O. McGinnis \& Michael B. Rappaport, Original Methods Originalism: A NewTheory of Interpretation and the Case Against Construction, 103 Nw U. L. REv. 751 (2009).
} 
The hallmark of the new originalism-and Balkin's theory-is its presentist commitment to the past. The Constitution is binding on government today because we the people today are committed to what the Constitution refers to as "this Constitution," by which is meant the writing itself. The institutions that are supposed to be governed by "this Constitution"- the executive, judicial, and legislative branches-cannot change its meaning unless they go through the appropriate procedures.

If this sounds odd, it should not. After all, even living constitutionalists often adhere to the original meaning of the judicial precedents they like. Yet there is no apparent conundrum associated with today's judges following faithfully the writings of long dead judges. We may not agree with what the Constitution says, any more than we may agree with what precedents may say. But there is no mystery about why "following the law" is not a slavish commitment to the past, but is rather a means of controlling the behavior of current actors who wield considerable power. What is odd, and ultimately unpersuasive to the general public today, is the proposition that those who are to be bound by the Constitution may remake the rules whenever the constraints imposed upon them become inconvenient to their objectives.

\section{A cautionary note about underlying principles}

In Living Originalism, Balkin offers a powerful defense of original meaning originalism, which he says is consistent with at least some vision of living constitutionalism. He identifies his approach as the method of "text and principle." This involves checking whether the text can "bear" a proposed constitutional construction and still make sense within the larger Constitutional scheme. ${ }^{17}$ However ingenious it may be to employ text and principle simultaneously in this manner, Balkin's account can nevertheless be read as blurring the useful line between interpretation and construction, and between the new originalism and the more traditional version of living constitutionalism.

For example, there is a danger in slipping from applying text and principle to applying text or principle instead. Balkin's methodology as presented would involve analyzing the text to check for plain meaning and turning to underlying principles if the original meaning is not clear. On his account, the underlying principle then becomes disembodied from the text and is applied generally, while leaving the text it supposedly underlies behind. When this happens, the method ceases to be originalism plus construction, and becomes all construction. Indeed, this is the way most living constitutionalism has always been practiced. Living originalists claim to be truer to the "principles" of the Constitution than those who would blindly follow the text. The term "living constitutionalism" was coined to justify ignoring or contradicting text in favor

\footnotetext{
${ }^{17}$ Balkin, supra note 1 at 254.
} 
of more dominant contemporary principles that are said somehow to derive from, or underlie, the text.

Closely related to this unrefined "text or principle" methodology is the notion that constitutional meaning is more of a continuum of rules on one end and open-ended standards on the other. In crucial places, Balkin turns the text into a more of a standard than the evidence of textual meaning would support. So, for example, although some a principle of "equality" may well underlie the clause protecting the "equal protection of the law," the words "protection" and "of the law" have a narrowing meaning that quickly gets jettisoned. Done properly, any resort to underlying principles must then reemerge through the text for it to be the text, rather than the disembodied principle, to provide the law of case.

I hasten to add that I do not think that Balkin is insincere in the methodological section of the book. But when executing the methodology, his old living constitutional self resurfaces. Though it is not irremediable, this looseness of his approach to constitutional construction may regrettably shift the focus from Balkin' momentous methodological breakthrough in uniting two opposing camps of constitutional scholarship. Instead, he leaves himself vulnerable to charges of opportunism. Both his critics on his left and on his right may charge that his supposed adoption of originalism is a feint. He only adopts originalist rhetoric because his "text and principle" approach to construction gets him everywhere he wants to go.

\section{Conclusion}

Balkin's Living Originalism is a major contribution to the debate over the proper method of constitutional interpretation. Whatever else one might think of his particular arguments, Balkin's conscious and deliberate adoption of "originalism" is a major cultural development in the legal academy. It will now be harder for die-hards to dismiss originalism as naive, ignorant, or evil. No legal academic I know is more savvy, knowledgeable, or decent than Jack Balkin. I welcome him to the growing club of new originalists. Secret handshake to follow. 